\title{
Indi@logs
}

Vol 8 2021, pp 51-73, ISSN: 2339-8523

https://doi.org/10.5565/rev/indialogs.172

\section{ReVisiting GandHI's IDEA OF TRUSTEESHIP IN THE CONTEXT OF GLOBALIZATION AND INEQUALITY}

\author{
STEFY V. JOSEPH \& MUCHELI RISHVANTH REDDY \\ Christ University, Bangalore \\ stefy.joseph@christuniversity.in \\ mucheli.reddy@arts.christuniversity.in
}

Received:19-10.2020

Accepted:03-02-2021

\begin{abstract}
Mahatma Gandhi's idea of trusteeship is a pragmatic model of development that aims to attain economic equality in society. This idea is an alternative to communism and capitalism and is based on nonviolence and inclusivity. Trusteeship seeks to resolve the conflict between labour and capital by emphasizing on equitable distribution of work and wages, giving equal importance to manual and mental labour, promoting people to labour for their own bread, creating a society in which all the people are entitled only to as much wealth as required to satisfy their needs and have time for leisure. Trusteeship replaces competition with cooperation by promoting wealthy people to voluntarily abdicate their wealth for the underprivileged. It aims to transform self-interested individuals to work for group-interest. This idea is relevant for the present times when inequality is widening the gap between rich and poor, and weakening the prospects of inclusive development. Trusteeship is a workable solution that can ensure sustainable progress in contemporary times.
\end{abstract}

KEYwORDS: Economic Equality; Trusteeship; Gandhi; Businessman; Globalization; Nonviolence; Property

\section{RESUMEN Repasando la idea de Gandhi de la tutela en el contexto de la globalización y la desigualdad}

La idea de administración fiduciaria de Mahatma Gandhi es un modelo pragmático de desarrollo que apunta a alcanzar la igualdad económica en la sociedad. Esta idea es una alternativa al comunismo y al capitalismo, y se basa en la no violencia y la inclusividad. La administración fiduciaria trata de resolver el conflicto entre el trabajo y el capital haciendo hincapié en la distribución equitativa del trabajo y los salarios, dando igual importancia al trabajo manual y al mental, promoviendo que las personas trabajen para ganar su propio pan, creando una sociedad en la que todas las personas tengan derecho a tanta riqueza como sea necesario para satisfacer sus necesidades y disponer de tiempo libre. La administración fiduciaria sustituye la competencia por la cooperación al promover que las personas ricas renuncien voluntariamente a su riqueza en favor de los menos privilegiados. Su objetivo es transformar a los individuos interesados en sí mismos para que trabajen por el interés del grupo. Esta idea es relevante hoy en día en los tiempos en que la 
desigualdad está ampliando la brecha entre ricos y pobres y debilitando las perspectivas de un desarrollo inclusivo. La administración fiduciaria es una solución a la vista viable y que puede garantizar un progreso sostenible en la época contemporánea.

Palabras Clave: Igualdad económica; administración fiduciaria; Gandhi, empresario; globalización; no violencia; propiedad

\section{Introduction}

Mohandas Karamchand Gandhi is one of the most influential personalities in the global arena even after 150 years of his birth. He is considered as the "only man, at least in our century, who has shown by his own practice, a way of life that suggests a hope of solution of the outstanding world problems of today" (Guha, 2014). Gandhi was a man of multiple agendas ${ }^{1}$ and his life, among many other things was "a series of often intense and long-running arguments" (Guha, 2018: xiii). He touched all aspects of human life, East and West, Charka and Machinery, Hinduism and Christianity, Environment and Economics, Science and Humanity, Religion and Insanity, Celibacy and Passions, English and Mother tongue, etc. His ideas are largely relevant and could act as alternative solutions to the human civilization of today that "is passing through critical times; it is confronting probably the worst-ever crisis in its existence, with its survival hanging in the balance right in front of us" (Mathai, 2019).

The main focus of this paper is the idea of economic equality as espoused by Gandhi throughout his life. This aim is very integral to Gandhi's ideas and he believes that in achieving this goal lies the "master key to non-violent Independence" (Gandhi M. K., 1941: 25). In order to attain this end, Gandhi articulated the economic doctrine of trusteeship ${ }^{2}$. It can be said that the economic ideas of Gandhi received less attention and the doctrine of trusteeship, in particular, was not very popular. This lack of attention on "the realm of economy and political economy around Gandhi is most glaring" (Suhrub, 2019), and not very surprising, because Gandhi was not an economic

\footnotetext{
1 "To deliver India from British rule was by no means Gandhi's only preoccupation. The forging of harmonious relations between India's often disputations religious communities was a second. The desire to end the pernicious practice of untouchability in his own Hindu faith was a third. And the impulse to develop economic self-reliance for India and moral self-reliance for Indians was the fourth" (Guha, 2018: xii). Gandhi pursued each of these agendas simultaneously, emphasizing one over the other at times, to achieve the India of his dreams.

2 Two remarkable works with regard to Gandhi's economic ideas are Kumarappa's An Economic Survey of Matar Taluka (1952) and Richard Gregg's Economics of Khaddar (1946).
} 
thinker in the conventional sense of the term and did not propose complex theories backed by mathematical sophistication. It is assumed that he "was presenting a vision of a utopia in which economic behavior had a far secondary role to the philosophical and political purposes of his ideas" (Rosen, 1982: 435). Josiah Olfield once remarked, as quoted in French (1934), Gandhi was considered to be "a problem.... To economists he is a hopeless ignoramus. To materialists he is a dreamer. To communists he is a drag on the wheel" (French, 1934: xiii). Gandhi's ideas seemed orthodox and antithetical to progress, and the idea of trusteeship was perceived to be discouraging towards entrepreneurship and development. But critical scrutiny into the meaning, sources and intentions of the economic doctrine of trusteeship as proposed by Gandhi will reveal its relevance "in spite of the ridicule that has been poured upon it" (Gandhi M. K., 1941: 25).

\section{Contextualizing the Idea of Trusteeship}

To understand the idea of trusteeship, it is imperative to understand the context in which Gandhi evolved his economic thoughts. Gandhi repeatedly experimented with myriad ideas that evolved continuously and he 'never made a fetish of consistency' ${ }^{3}$. Gandhi reserved "his freedom to jettison ideas which he thought wrong or outdated, and to espouse new ones which he considered desirable" (Srinivas, 1995: 1489). He also mentioned that "when anybody finds any inconsistency between any two writings of mine, if he has still faith in my sanity, he would do well to choose the latter of the two on the same subject" (Gandhi M. K., 1956: 4).

Despite this inconsistency, a common element found in Gandhi's thinking is the way he acted in the face of any crisis. Gandhi always sought alternatives (Mathai, 2019) for transforming the conditions of an existing order of things. Instead of bringing changes to the existing order of things, Gandhi sought to create newer alternatives, showed new solutions and tried to push humankind, not only Indians but people across the world ${ }^{4}$, to imagine and strive for "a civilization that perhaps the world has not yet seen" and "not bow to the conventions of European Civilization" (Gandhi R., 2019: 38). His quest for alternatives was explicit in Gandhi's critique against Western

\footnotetext{
${ }^{3}$ Writing an introduction to a booklet of his writings on varna dharma, Gandhi wrote that he "has never made a fetish of consistency. I am a votary of truth and I must say what I feel and think at a given moment on the question, without regard to what I may have said before on it" (Gandhi M. K., 1999: 62).

${ }^{4}$ Gandhi once declared that "In trying to serve India, I serve humanity at large" (Mehta G. L., 1969). His ambition is "nothing less than to see international affairs placed on a moral basis through India's efforts" (Mehta G. L., 1969).
} 
Civilization in his pioneering work Hind Swaraj, in which Gandhi made "a proclamation of ideological independence" (Dalton, 1993: 16) that outrightly resisted the indiscriminate encroachment of the West ${ }^{5}$. This way of thinking makes Gandhi, arguably, the most radical and relevant individual of his times and after. All the ideas of Gandhi can be viewed from this lens of developing alternatives, for which the trusteeship is not an exception. The doctrine of trusteeship should also be looked at from the larger framework of Gandhi's efforts to evolve workable alternatives to the existing status quo.

The idea of trusteeship is an outcome of Gandhi's search for a solution to fulfill his "concern for economic equality" (Chakrabarty, 2017). Gandhi propounded that it is only by achieving economic equality that India can claim to have achieved 'complete independence' (Gandhi M. K., 1941: 3) and he strongly believed that for "political freedom to be meaningful [it] needed to be complemented by economic equality" (Chakrabarty, 2017). He cautioned that if economic equality is not attained, then "a violent and bloody revolution is a certainty one day" (Gandhi M. K., 1941: 25). But it is also important to recognize that Gandhi is not searching for economic equality through the idea of trusteeship single-mindedly. He is evolving a pragmatic idea that serves many purposes, including its explicit aim of achieving equality.

The idea of trusteeship serves as an alternative to the methods of "scientific socialism and communism sponsored by western thinkers" (Rao, 1970). Gandhi was well aware of the ideas of socialism and communism, and the methods employed by these ideologies to achieve economic equality. Gandhi recognized that he was "engaged in solving the same problem that faces scientific socialists" (Gandhi M. K., 1947: 22). However, apart from certain commonalities, there are sharp differences between western socialism and Gandhi's conception of socialism ${ }^{6}$. When asked about

\footnotetext{
${ }^{5}$ Gandhi confessed that his "resistance to Western civilization is really a resistance to its indiscriminate and thoughtless imitation based on the assumption that Asiatics are fit only to copy everything that comes from the West...I do believe that if India has patience enough to go through the fire of suffering and to resist any unlawful encroachment upon her own civilization which, imperfect though it undoubtedly is, has hitherto stood the ravages of time, she can make a lasting contribution to the peace and solid process of the world" (Gandhi M. K., 1947: 4-5).

${ }^{6}$ According to Gandhi, "Real socialism has been handed down to us by our ancestors who taught: "All land belongs to Gopal; where then is the boundary line? Man is the maker of that line and he can, therefore, unmake it." Gopal literally means shepherd; it also means God. In modern language it means the State, i.e., the People. That the land today does not belong to the people is true, but the fault is not in the teaching. It is in us who have not lived up to it. I have no doubt that we can make as good as approach to it as is possible for any nation, not excluding Russia, and that without violence. The most effective substitute for violent dispossession is the wheel with all its implications. Land
} 
what he meant by economic equality in a Constructive Worker's Conference that was held at Madras in 1946, Gandhi said:

economic equality of his [Marx] conception did not mean that everyone would literally have the same amount. It simply meant that everybody should have enough for his or her needs. For instance...the elephant needs a thousand times more food than the ant, but that is not an indication of inequality. So, the real meaning of economic equality was: "To each according to his need". That was the definition of Marx. If a single man demanded as much as a man with wife and four children that would be a violation of economic equality (Gandhi M. K., 1960: 11).

Both Gandhi and Marx in their writings aimed at achieving economic equality. But there is significant divergence in the idea sought by Marx and Gandhi on what they mean by equality and the method to attain the same. Marx's idea to achieve economic equality is centered around the abolition of private property. According to Marx, the notion of equality is primarily political, as it proposed the 'abolition of classes' on the route to achieve equality (Wood, 2014: 255-255). In contrast, Gandhi's idea of equality seems to be more radical than that of Marx. Instead of just focusing on private property, Gandhi recognized the inequalities that arise "from differences in human skills or responsibilities" (Rao, 1970: 29). In accordance with their available skills, individuals should not seek to amass more than what is required to fulfill their needs. If individuals have more wealth after fulfilling their needs, they should act like trustees of that excess wealth and use it for the public good. This process will lead to the establishment of an egalitarian society where every individual's needs are fulfilled and it would also eliminate the necessity of coercive class war to achieve equality.

The second point of divergence between Marx and Gandhi stems from the means to attain equality. Marx theorized "the trajectory of capitalist development as a negatively skewed economic system with in-built seeds of self-destruction doomed to be heading for the inevitable collapse" (Gurukkal, 2012: 66) and envisioned an inevitable violent proletarian revolution that would result in forced encroachment of private property from the propertied classes which would finally culminate in creating an equal society. Like Marx, Gandhi perceived that "a violent and bloody revolution [would be] a certainty one day unless there is a voluntary abdication of riches and the power that riches give and sharing them for the common good" (Gandhi M. K., 1941: 25). But Gandhi does

and all property is his who will work for it. Unfortunately, the workers are or have been kept ignorant of this simple fact” (Gandhi M. K., 1947, pp. 22-23). 
not advocate the forced dispossession from those who have got possessions. His method to level the gap between rich and poor is associated with faith in non-violence and human righteousness, and Gandhi does not want to compromise on the latter to attain his objective of economic equality. It is a well-acknowledged fact that Gandhi wanted non-violence in everything ${ }^{7}$. He opposed class hatred and the need for a class war to end economic inequalities. Gandhi wanted to use nonviolence as a weapon in pursuing his economic ideal of trusteeship. He found that no theory other than trusteeship is "compatible with non-violence" (Gandhi M. K., 1947: 69). So, Gandhi's trusteeship serves as an "Indian alternative to the Western technique of scientific socialism and communism for the bringing into existence of a just, egalitarian and humane new social order" (Rao, 1970: 57).

The doctrine of trusteeship stood as an alternative to the path of development proposed by western capitalism. In his book Hind Swaraj, which is considered to be a 'Gandhian Manifesto' (Mathai, 2019), Gandhi wrote that western civilization promotes immorality. In contrast, Indian civilization propagates moral beings (Gandhi M. K., 1938). Gandhi diagnosed that the western model of economy inherently promotes competition and violence. According to him, western civilization is "rooted in and sustained by violence both direct and structural, and consequentially, it generated and escalated more violence" (Mathai, 2019). Gandhi cautioned that western civilization holds in within it the ability to destroy the morality of mankind since it elevated the "bodily welfare" (Gandhi M. K., 1938) as the object of life. Gandhi understood the limits of the world to provide for everyone's needs and not beyond that. He propounded that the western model of development is characterized by exploitation, and if India adopts a similar path, then like England and America, India has "to find some other races and places of the earth for exploitation" (Gandhi M. K., 1999: 381). If India takes the same path as the west by forging competition and consumerism, then it would create unimaginable problems for the world. In 1928, Gandhi expressed his concerns about India adopting the western model of development:

\footnotetext{
${ }^{7}$ One of the greatest contributions of Gandhi to the modern world is his method of non-violence. Non-violence as a method was largely practiced at individual levels throughout history, it was Gandhi who gave it the largest collective expression and used it as "a mass instrument for the restoration of human dignity" (Rao, 1970: 57). Gandhi declared"I hold that nonviolence is not merely a personal virtue. It is also a social virtue to be cultivated like other virtues. Surely society is largely regulated by the expression of nonviolence in its mutual dealings. What I ask for is an extension of it on a larger, national and international scale" (Gandhi M. K., 1947: 69).
} 
God forbid that India should ever take to industrialism after the manner of the West. The economic imperialism of a single tiny island kingdom (England) is today keeping the world in chains. If an entire nation of 300 million took to similar economic exploitation, it would strip the world bare like locusts. Unless the capitalists of India help to avert that tragedy by becoming trustees of the welfare of the masses and by devoting their talents not to amassing wealth for themselves but to the service of the masses in an altruistic spirit, they will end either by destroying the masses or being destroyed by them (Gandhi M. K., 1999).

The important phrase in the above quote is 'manner of the west' and this is the manner to which Gandhi seeks to show an alternative with his idea of trusteeship.

Gandhi seeks to resolve the eternal conflict between labor and capital. Gandhi believed that "working for equality means abolishing the eternal conflict between capital and labor. It means the levelling down of the few rich in whose hands is concentrated the bulk of the nation's wealth on the one hand, and the levelling up of the semi-starved naked millions on the other" (Gandhi M. K., 1941: 25). He believed that until this conflict between capital and labor, rich and poor is resolved, the wholesome fulfillment of Independence is a distant goal. Gandhi was also aware of the fact that this leveling up of rich and poor had to be done without antagonizing the holders of capital and labor. Gandhi resolved to find a point of compromise between the interests of both sections which would satisfy both and at the same time, pave the path for achieving his goal of economic equality. Precisely, Gandhi tried to create a doctrine that would forge 'class-compromise' (Chakrabarty, 2017). This compromise is imperative because, in his struggle for Independence, Gandhi wanted the active participation of all classes. Gandhi realized that if he aimed at achieving equality outrightly, then it would inevitably lead to class war and the anti-imperialist movement "could ill-afford an all-out class war between the constituent classes of the merging nation" (Mukherjee, 2016).

In the struggle for Independence in India, it is the masses that played an important role in the movement against the imperialists. Gandhi's messages permeated the consciousness of the masses and filled them with new hope and zeal to sacrifice for the nation. On the other hand, Gandhi needed the support of big capitalists, who have substantial financial power. Gandhi and the Congress Party depended on the funds from the capitalists and merchant princes for carrying out their activities (Mehta V., 1976). This dependence on capitalists, coupled with Gandhi's opposition to forced dispossession of wealth from these wealthy classes led critics to suspect that Gandhi was being 'soft' to the wealthy people (Chakrabarty, 2017). Critics claimed that Gandhi "obliged the 
princes, the Zamindars, the capitalists and holders of power by subtly furnishing them one more weapon to cling to their respective position of advantage" (Mashruwala, 1951: 77).

Gandhi wanted to live like a poor man, and reduce himself "to the level of the poorest of the poor" (Gandhi M. K., 1960: 10). He also popularized the notion of Daridranarayan as "one of the millions of names by which humanity knows God who is unnamable and unfathomable by human understanding and it means God of the poor, God appearing in the hearts of the poor" (Gandhi M. K., 1929: 206). Despite this conviction to live in poverty, Gandhi had to move from one corner to another corner of the country to promote his social and political programs. For this reason, it is not easy "to maintain Gandhi in his exacting, simple style of life, especially when he and his entourage were travelling from village to village or from continent to continent" (Mehta V., 1976: 56) and this required financial support. The support came from people like "Ambalal Sarabhai, Jamanlal Bajaj, and Ghanshyam Das Birla—who were among his followers" (Mehta V., 1976: 56). There are also businessmen like "Vadilal Lallubhai Mehta, Samuel Aaron, Lala Shankar Lal, and others... who went to jail and accepted the hardships" during the national movement. For Gandhi, the support of the capitalist class was necessary for both financial and political terms. He did not want to distance this class from the national movement. It is for this reason, coupled with his commitment towards non-violence, that Gandhi did not support the forced dispossession of capital from the capitalists. He advocated the voluntary abdication of wealth by the rich and to "reduce oneself to the level of the poorest of the poor" (Chakrabarty, 2017).

Therefore, Gandhi's doctrine of trusteeship was designed to serve multiple purposes - it is a critique of and an alternative to the methods of scientific socialism, communism, and the western model of development. It also seeks to push the wealthy to abdicate their wealth voluntarily for the sake of the underprivileged classes. Gandhi's trusteeship should be analyzed in light of these three purposes to understand it holistically.

\section{Principles of Trusteeship}

Gandhi's idea of trusteeship is based on a theological idea (Chakrabarty, 2017), from the first 
sloka $^{8}$ of Isopanisad ${ }^{9}$, that God is the supreme owner of this universe and all the resources in it. Human beings are just 'trustees' of the resources on the planet. Human beings will work and earn what "they need for their sustenance [which means] that they enjoy [the fruit of labour] not as proprietors but as trustees" (Parel, 2006: 70).

It is important to emphasize Gandhi's notion of work, which was influenced by his readings of works by John Ruskin and Leo Tolstoy ${ }^{10}$. Like Ruskin, Gandhi too believed in the importance of work to earn a living and create an equitable society. He was of the opinion that "God created man to work for his food, and said that those who ate without work were thieves" (Gandhi M. K., 1999: 414). Gandhi is completely against people who do not work and still have bread to eat. Reflecting on those people who do not care to work, Gandhi believed that "the great Nature has intended us to earn our bread in the sweat of our brow. Everyone therefore who idles away a single minute becomes to that extent a burden upon his neighbours" (Gandhi M. K., 1999: 225). Secondly, Gandhi also says that no individual should be deprived of enjoying the fruits of their labor. This will ensure the dignity of labor and ascribe respect to the work done. Another aspect of this proposition is that the individual should enjoy and appropriate wealth only to a limit that can satisfy their needs and the one who "appropriates more than the minimum that is really not necessary for him is guilty of theft" (Gandhi M. K., 1960: 3). The only way to avoid this type of thievery is to understand "in what capacity persons having actual control over and possession of the property should be deemed to have it or in what spirit they should be suffered to possess it. Gandhiji says that... where persons possess property, whether that possession is vested in them in a manner deemed legal at the time or otherwise, they must be deemed to hold it in trust for society and not for themselves". (Mashruwala, 1951: 78). In simple terms, "when an individual had more than his proportionate portion, he becomes a trustee to that portion for God's people" (Gandhi M. K., 1960:

\footnotetext{
${ }^{8}$ A Sanskrit word meaning "song" which typically has 4 verses.

${ }^{9}$ The sloka in translation: Everything animate or inanimate that is within the universe is controlled and owned by the Lord. One should therefore accept only those things necessary for himself, which are set aside as his quota, and one must not accept other things, knowing well to whom they belong" (Śrī İśopaniṣad, Mantra 1, 1970).

${ }^{10}$ Ruskin and Tolstoy are two great influences on Gandhi's economic ideals. Gandhi confessed that "The law, that to live man must work, first came home to me upon reading Tolstoy's writing on bread labour. But, even before that I had begun to pay homage to it after reading Ruskin's Unto This Last. The divine law, that man must earn his bread by labouring with his own hands, was first stressed by a Russian writer named T.M. Bondaref. Tolstoy advertised it and gave it wider publicity. In my view, the same principle has been set forth in the third chapter of the Gita where we are told that he who eats without offering sacrifice eats stolen food. Sacrifice here can only mean bread labour" (Gandhi M. K., 1960).
} 
5). It is important to note that Gandhi is not just emphasizing that private property falls under the category of trusteeship. In Gandhi's conception,

the theory of trusteeship makes no distinction between private and non-private property. All property is held in trust, no matter who possesses it, and what its nature or quality is. Indeed, the theory of trusteeship applies not only to tangible and transferable property, but also to places of power and position and to intangible and non-transferable property such as the muscular energy of a labourer and the talents of a Helen Keller. Even a cripple in an asylum for invalids is a trustee to the extent he is able to exercise his will. Every human being not mentally deranged is only a trustee of all that is within his control (Mashruwala, 1951: 79-80).

After reflecting on the importance of work and labor and the nature of the property that could be falling under trusteeship, Gandhi turned to reflect on the nature of work that has to be done under trusteeship for leveling the ground between rich and poor, which is the core aim of trusteeship. Gandhi resolved this conflict by addressing the distinction between manual and mental labor and emphasizing the need for bread labor. Gandhi realized the huge disjunction in the nature of manual and mental labors. Gandhi sought to create

a society of equals, limited in their material wants, with all of the participants engaged in manual and intellectual tasks of equal prestige, receiving incomes based on needs and thus relatively equal. He objected to growth characterised by a competitive striving for wealth and power with ever increasing, artificially created wants (Rosen, 1982: 435).

In the society of Gandhi's conception, “a lawyer's work has the same value as the barber's, as all have the same right of earning their livelihood from their work" (Gandhi M. K., 1956: 3), i.e., they should be able to get "sufficient goods to meet their basic needs" (Rosen, 1982: 435). So, Gandhi is clearly seeking to emphasize the need for physical and intellectual labor. But for him, physical labor is more important than mental labor. This is because, during his time, it was not possible to train the semi-naked and starving millions to get engaged in intelligent work (mental labor). He ascertained that

intelligent labour is for the time being the only primary and adult education in the land of starving millions... Literary education should follow the education by hand - the one gift that visibly distinguishes man from beast. It is a superstition to think that the fullest development of man is impossible without a knowledge of the art of reading and writing. That knowledge undoubtedly adds grace to life, but it is in no way indispensable for man's moral, physical, or material growth (Gandhi M. K., 1947: 190). 
Further, Gandhi examines, "May not men earn their bread by intellectual labour? No. The needs of the body must be supplied by the body. Mere mental, i.e. intellectual labour is for the soul and its own satisfaction" (Singh, 2006).

The concept which Gandhi elucidated in his conviction for need of physical labor over mental labor, drawing the inspiration from the Russian peasant writer, T. M. Bondaref, is the thesis of 'bread labour"11 which means that "man must earn the bread by laboring with his own hands" (Rao, 1970: 12). He said that there "is a world-wide conflict between capital and labour, and the poor envy the rich. If all worked for their bread, distinction of rank would be obliterated; the rich would still be there, but they would deem themselves only trustees of their property, and would use it mainly in the public interest" (Singh, 2006: 144).

Gandhi found a great utility in practicing this ideal because "if all labored for their bread and no more, then there would be enough food and leisure for all" and this can act as a tremendous equalizer, because when everyone labors for their own bread, "there will then be no rich and no poor, none high and none low, no touchable and no untouchable" (Gandhi M. K., 1947: 58). He believed that when all people work their own hands to earn bread, then everyone will realize the dignity of work. Performing bread labor is a responsibility of every Indian, including the British Governor, "who naturally represents the British might.... should represent hand spinning as a visible token of identification with the dumb millions of India, a token of the necessity of 'bread labor' and organized nonviolence as against organized violence on which the society of today seems to be based" (Gandhi M. K., 1947: 286).

There are certain misconceptions around the idea of trusteeship. Critics are of the opinion that trusteeship discourages the development of machinery and enterprise that are considered to be prerequisites for the growth of the nation. This criticism is limited and does not take into consideration the idea of trusteeship as a whole. It is true that Gandhi "considered the enterprise

\footnotetext{
${ }^{11}$ Though the idea of 'bread labour' had existed before, it is Gandhi who preached and practiced it with unflinching certitude. For Gandhi, "Bread-labour is a veritable blessing to one who would observe non-violence, worship truth and make observance of Brahmacharya a natural act. This labour can truly be related to agriculture alone, but at present at any rate, everybody is not in a position to take to it. If this is impossible, each family should see to its own scavenging. Evacuation is as necessary as eating, and the best thing would be for everyone to dispose of his own waste" (Singh, 2006).
} 
undesirable, and in his society unnecessary" (Rosen, 1982: 436). This is because Gandhi's primary objective was to address the needs of the semi-naked and starving millions. It would be disastrous to encourage machinery without attaining an equitable society because "the present use of machinery tends more and more to concentrate wealth in the hands of a few in total disregard of millions of men and women whose bread is snatched by it out of their mouths" (Gandhi M. K., 1947: 30). He believed that once all the people are provided with limited needs, then "whatever initiative becomes necessary would arise spontaneously from the social order in which the "new man" of that society lived" (Rosen, 1982: 436). Besides this, in the Indian context, there is a logical economic rationale behind Gandhi's emphasis on the desirability and importance of manual labor - he recognized the capability of human resources in India. His stress on manual labor needs to be seen in corollary:

to stress on developing labor-intensive techniques that would use India's abundant human resources, rather than machine-intensive techniques that led to greater unemployment and waste of human resources. All of these would bring out skills and interests and creative entrepreneurial energies currently unknown or underutilized in India; thus, they would contribute to economic growth and improved well-being for the mass of the Indian population (Rosen, 1982: 437).

Another major misconception is to look at trusteeship as mere philanthropy and trustee as being someone with generous philanthropic urges.

It is also supposed that the best trustee of Gandhiji's conception was no more than a man with some philanthropic urges. For instance, if there was a Raja or a millionaire who lived a simple personal life, now and then gave handsome donations, founded good charitable institutions, or made a charitable trust of a part of his property, and if in addition to this, he was also kind to his servants, civil in his general behaviour towards the poor, a hospitable host, obliging to friends, free from gross vices and a 'church-going man' (as he would be called in England), nothing more was to be expected of him to fulfill the obligations of a trustee. His personal household budget, or the manner in which he acquired his wealth was not to be inquired into" (Mashruwala, 1951: 77).

This too is a parochial understanding of trusteeship because Gandhi is aiming to level the gap between rich and poor by changing the attitudes of the people from just working for the self to working for others. The idea of trusteeship is rooted in what Gandhian Economist J. C. Kumarappa calls, 'Economy of Gregation' which means "extension from self-interest to group interest" (Kumarappa J., 1945). Gandhi wanted the wealthy to move beyond 'some philanthropic urges' and dispossess their wealth completely after satisfying their needs. If one owns a property and "for any reason, he does not need it, and may not require it in the near future, he should give it over to 
one who needs it" (Mashruwala, 1951: 82) and in this scenario, expropriation would be unnecessary and unjust because "present holders consent to fulfil the obligation of trustees" (Mashruwala, 1951: 82).

The core idea of philanthropy, which emerged as an offshoot of capitalism in recent decades is "about giving away surplus wealth without necessarily questioning the economic system which allows for such concentration of wealth" (Bakshi, 2013), whereas trusteeship aims at preventing the concentration of wealth. There is a growing debate around the question of how the wealthy philanthropists could influence the democratic institutions because "a big portion of the money pledged will probably flow into foundation endowments rather than being donated immediately to areas like education and services" (Strom, 2010). This leads to an increase in the net worth of mega-foundations operating globally that are capable of influencing the global policy making ${ }^{12}$.

There has been suspicions raised on the technology-driven innovative philanthropic activities carried out by billionaires, especially the Bill and Melinda Gates Foundation, which aims at harnessing "advances in science and technology to save lives in developing countries" (Dentico, 2020: 161) and help in solving global problems. A report titled 'Gates to a Global Empire' published by Navdanya, an NGO based in India founded by Vandana Shiva, closely examines the initiatives of the Bill and Melinda Gates Foundation. The report focusing on the Foundation's initiatives in the areas of health, agriculture, gene editing and promotion of technological solutionism concluded that "Bill gates and his fellow private business partners, as always, will continue to produce exponentially worse problems than the ones they propose to 'solve' while simultaneously working to concentrate ever more power into corporate hands". They are evidently using the tool of philanthropy to increase their global influence, without actually solving the problems, they rather compound them. Only the route of trusteeship could effectively address all the negative ills of philanthropic activity by aiming at breaking any structures that lead to the concentration of power and wealth (Cortes, 2020: 15).

\footnotetext{
12 The popularity around the Giving pledge initiative generated "fears that philanthropy is being used to bend public policy, whether it is the Koch brothers' support of conservative causes, the financier George Soros's donations to Democratic causes or the Gates Foundation's grants to promote charter schools" (Strom, 2010).
} 
Another major criticism on Gandhi's ideas of trusteeship could be found in the writings of Dr. B. R. Ambedkar. According to Ambedkar, the "special feature of Gandhism is that its philosophy helps those who have, to keep what they have and to prevent those who have not from getting what they have the right to get" (Ambedkar, 1991: 291). For Ambedkar,

The idea of trusteeship which Gandhism proposes as a panacea by which the moneyed classes will hold their properties in trust for the poor is the most ridiculous part of it. All that one can say about it is that if anybody else had propounded it the author would have been laughed at as a silly fool who had not known the hard realities of life and was deceiving the servile classes by telling them that a little dose of moral rearmament to the propertied classes - those who by their insatiable cupidity and indomitable arrogance have made and will always make this world a vale of tears for the toiling millions - will recondition them to such an extent that they will be able to withstand the temptation to misuse the tremendous powers which the class structure gives them over servile classes (Ambedkar, 1991: 286).

This criticism on the trusteeship doctrine should be viewed from the pervasive nature of the caste system and its connection with the economic entitlements in Indian society. In her essay 'The Doctor and The Saint', Arundhati Roy (2017: 29) observed that "in big business and small, in agriculture as well as industry, caste and capitalism have blended into a disquieting, uniquely Indian alloy. Cronyism is built into the caste system". In Indian society, where a hierarchical caste system has deeply permeated the social fabric, an individual at "the top of the caste pyramid is considered pure and has plenty of entitlements. The bottom is considered polluted and has no entitlements but plenty of duties" (Roy, 2017: 23). Ambedkar viewed that Gandhi was trying to reform the caste system from within without fundamentally attacking its exploitative structures ${ }^{13}$.

In line with Ambedkar's thinking, Arundhati Roy also viewed that, in the conditions where the caste and class are interconnected, the idea of trusteeship would only help the people at the top of the caste pyramid. Roy viewed trusteeship as a safe abode for capitalists because it would "echo almost verbatim what American capitalists - the Robber Barons-like J.D. Rockefeller and Andrew Carnegie were saying at the time" (Roy, 2017: 91), and Gandhi himself never confronted capitalists and landed aristocracy directly. Gandhi did not oppose capitalists outrightly because he aimed at bringing all classes together to fight against the colonial rule. He proclaimed boldly that

\footnotetext{
${ }^{13}$ In his work 'Annihilation of Caste', Ambedkar described that, what Gandhi seems "to suggest in its broadest and simplest form is that Hindu society can be made tolerable and even happy without any fundamental change in its structure, if all the high-caste Hindus can be persuaded to follow a high standard of morality in their dealing with the low-caste Hindus. I am totally opposed to this kind of ideology" (Ambedkar, 2017: 340).
} 
“Caste Has to Go" (Gandhi M. K., 1999: 121-22) and envisioned an egalitarian society. But to bring about this change, he did not subscribe to the idea of caste and class revolutions because any revolution would prove costly for India. Gandhi also opposed the idea of giving the State the responsibility to enforce trusteeship ${ }^{14}$. To address the issue of entangled interaction between class and caste, and to create an egalitarian society, Gandhi placed his trust on the innate morality of individuals to take part in bread labour and to act like trustees of the excess wealth for the public good.

Thus, the doctrine of trusteeship is a complex and pragmatic idea, based on nonviolence and inclusivity, a workable alternative to capitalism and communism, which seeks to bring about economic equality through the equitable distribution of work, giving equal importance to manual and mental labor, promoting people to labor for their own bread, creating a society in which all the people are entitled only to as much wealth as required to satisfy their needs and have time for leisure.

\section{The Relevance of Trusteeship in the Context of Globalization}

Though the world has changed a lot since Gandhi developed his idea of trusteeship, it remains relevant even in the present times. The international scenario has changed by and large since then and countries across the world have become transformed and integrated through the process of globalization. It laid down the foundations for a "society which has been characterised as a knowledge society... an age of explosion of and access to information and knowledge" (Mathai, 2019: 13) that promoted competition, a greater urge for wealth, status, power and created a "commercial society of self-interested rational individuals...in which human beings are programmed to maximize their self-interest" (Mishra, 2017). But these ideals of globalization have pushed humanity into a vicious circle of crises. In contrast to the normative ideals propagated by globalization, what it has actually resulted in, as Indian essayist Pankaj Mishra calls it, is an 'Age of Anger':

\footnotetext{
${ }^{14}$ According to Gandhi, the State represented "violence in a concentrated and organised form. The individual has a soul, but as the State is a soulless machine, it can never be weaned from violence to which it owes its very existence. Hence I prefer the doctrine of trusteeship".
} 
The crisis of recent years has uncovered an extensive failure to realize the ideals of endless economic expansion and private wealth creation. Most newly created 'individuals' toil within poorly imagined social and political communities and/or states with weakening sovereignty. They not only suffer from the fact that, as Tocqueville wrote in another context, 'traditional ties, supports and restrictions have been left behind along with their assurances about a person's self-worth and identity'. Their isolation has also been intensified by... junking of social democracy by globalized technocratic elites... Individuals with very different pasts find themselves herded by capitalism and technology into a common present, where grossly unequal distribution of wealth and power have created humiliating new hierarchies (Mishra, 2017).

In this Age of Anger, universally, humankind "has reached such a degree that it can experience its own destruction as aesthetic pleasure of the first order" (Benjamin, 2020). The process of globalization unleashed the economics of "tyranny" that has "notoriously reduced a question that dogged political philosophers for centuries - about how much harm is acceptable in a society_to a math problem" (Kaiser-Schatzlein, 2019). Globalization served the interests of a smaller section of society standing at the top of the economic ladder and deprived the livelihood entitlements of the large sections of the people living at the bottom of the economic ladder. The situations that are stated above, which are globally observed, are also prevalent in India.

Though India claims to be a growing economy, it is still a land of poverty, hunger and disease. In a report published by the World Economic Forum (2020: 10), it is forecasted that "Indians born in low-income families would take seven generations to even approach the country's mean income". Two hundred million people in India have an expenditure of less than Rs. 32 per day (Mahapatra, 2020). On the other hand, there are 119 billionaires in India. It is surprising to realize that "between 2018 and 2022, India is estimated to produce 70 new millionaires every day. It would take 941 years for a minimum wage worker in rural India to earn what the top paid executive at a leading Indian garment company earns in a year" (Himanshu, n.d.). This widening gap between rich and poor in India's case is more worrying because "economic inequality is being added to a society that is already fractured along the lines of caste, religion, region and gender" (Himanshu, n.d.). The global crisis, which the whole world is now involved in combating, has further intensified the economic inequalities in India. Around "121 million more people are on the brink of starvation due to mass unemployment, disruption to food production....12,000 people could die every day from COVID-linked hunger" (Mahapatra, 2020). If the present state of affairs is left as it is, then certainly, the situation is going to get worse. It is high time to realize that the route of capitalism 
and globalization cannot save humanity. It is time to adopt an alternative solution for present-day problems. It is in this context that Gandhi's doctrine of trusteeship could offer a workable alternative.

In 2013, "Indian government legislation mandated for compulsory spending of $2 \%$ of the Company's net profit in social development work by the Corporates" (Chauhan, 2019: 370). This is a good move that is in line with the idea of trusteeship. But the mere allocation of funds is not enough. It is the responsibility of the corporates to "ensure basic human dignity for equitable distributive justice and lowering income disparity" (Chauhan, 2019: 370). More resolute moves are needed to address the deep-rooted inequalities. In order to prevent the exploitation of labor, a standard wage for work and for hours of leisure could be enforced throughout the country. People should be encouraged, without the use of coercion, to do the work that they enjoy doing. As Gandhi said, "the farmer who cuts his hay at the right time; the builder who lays good bricks in welltempered mortar; the house-wife who takes care of her furniture in the parlour and guards against all waste in her kitchen are all political economists in the true and final sense, adding continually to the riches and well-being of the nation to which they belong" (Gandhi M. K., 1956: 18). The idea that follows the above proposition of promoting people to do the work of their interest is to promote livelihoods through developing indigenous industries, arts and crafts in which certain sections of people are involved for generations.

In a study conducted by the Anthropological Survey of India, it is estimated that "there were at least 276 non-pastoral nomadic occupations" (Shrivastavsa \& Kothari, 2012) and most of these occupations ${ }^{15}$ are "threatened, some already extinct or dying, and the people displaced from these livelihoods are either getting absorbed into insecure, undignified, low-paid, and exploitative sectors of unorganized labour, or are left self-employed [and] the same holds for 40 million pastoral nomads" (Shrivastavsa \& Kothari, 2012) living in India. These occupations must be protected because it is where indigenous people can exhibit their productive abilities. By providing support to these indigenous occupations, the Indian market can bloom with a wide variety of products and also increase the global demand for such products, which will aid the growth of the

\footnotetext{
${ }^{15}$ Non-pastoral nomadic occupations include "hunter-gatherers and trappers, fishers, crafts persons, entertainers and story tellers, healers, spiritual and religious performers or practitioners, traders, and so on" (Shrivastavsa \& Kothari, 2012).
} 
Indian economy. It will enable indigenous people to earn their livelihood and ensure dignity for their labor.

One of the core ideas of trusteeship is to promote bread labor by all human beings. In order to attain this ideal, businessmen should be encouraged to set up labor-intensive industries in the rural areas where large numbers of human resources are left unutilized or underutilized. As a visible token of identification with the workers, the capitalist owners can tone down their extravagant lifestyle and be aware of the living conditions of the workers.

Trusteeship aims at ensuring individuals use their labor for fulfilling their needs and preventing them from exploitation and deprivation. To pursue this objective, laboring individuals should be given the power to decide on how they want to use their labor. The Anna Swaraj Movement that was launched in India in 2015 provides a workable model to achieve this objective (Shiva, 2015). This movement was launched to protect farmers from agribusiness capitalists exploiting farmer's produce by coercing them to produce and sell their products in the interest of corporates. Anna Swaraj or The Food Sovereignty movement strives "for a food and agriculture revolution aiming at food democracy with the participation of citizens and all levels of government, from the local, to the state, to the national level" (Shiva, 2015). The movement provides support to farmers to produce crops that best suit their land, provide them with quality seeds produced organically and using organic farming techniques. Its aims are to take food directly from producers to consumers in order to prevent the adulteration of food and thus benefit both producers and consumers.

Gandhi's idea of trusteeship aims at creating an equitable society where people can satisfy their needs. This is possible through promoting a decentralized system of governance that allows villages to be self-reliant with all the resources they need so that they will be able to depend less on goods and services from outside the village. Each village should function as a trust with the villagers as trustees. All the resources, that are produced in excess of the requirements of the village, should be pooled in the trust, and these excess resources should be utilized for the development of the village. There are numerous instances in India where initiatives have been taken in certain villages and tribal groups that employ Gandhian economic principles in administering their regions. "Ralegan Siddhi and Hivara Bazaar in the state of Maharashtra, those 
in Dewas district of Madya Pradesh where Samaj Pragati Sahayog is active, and those in Alwar district of Rajasthan where Tarun Bharat Sangh works" (Shrivastava \& Kothari, 2012: 12-13) are cases in point. In these regions, people come together to make decisions collectively about production, ways to use the resources, inter-village cooperation, and solving the problems in the village. These regions have moved towards becoming self-reliant by fulfilling the basic needs of all the people living in their villages. The models exemplified by these villages can be adopted across India and throughout the world.

The broader idea, that is implicitly exemplified above, is the need to plan for growth and welfare from the bottom, and to remodel the development strategies from a "local to global" perspective. The development in India should begin from the villages. This move requires state support and commitment for the structural decentralization of power. Creating self-reliant villages and selfsufficient individuals is the first step towards claiming progress in the country. To realize these objectives, Gandhi's doctrine of trusteeship offers a practical framework that could be emulated.

\section{Conclusion}

In the contemporary world, when humankind is going through critical times, Gandhi's ideas can offer the world a way out of madness. His doctrine of trusteeship is a sustainable and workable alternative for humanity to adapt and progress. The idea of trusteeship is "created for all of us. It is not against creation and accumulation of capital" (Suhrub, 2019). It is not an idea against progress. It is an idea based on faith in humanity to work for its collective good. It is an idea based on the quintessential nature of the earth that can provide for everyone's needs without compromising the needs of anyone on this planet. Replacing competition with cooperation, violence with non-violence and class hatred with mutual respect and service, trusteeship can ensure peaceful, inclusive and sustainable development on this planet.

An equitable society based on trusteeship is not an easy ideal to achieve, but certainly, it is a plausible alternative that has the potential to be a savior of humanity. As Gandhi said, "Absolute trusteeship is an abstraction like Euclid's definition of a point and is equally unattainable. But if we strive for it, we shall be able to go further in realizing a state of equality on earth, than by any other method" (Gandhi M. K., 1999: 318). 


\section{WORKS CITED}

AMBEDKAR, B. R. (1991). "What Congress and Gandhi have done to the Untounchables". In: V. Moon (Ed.), Dr. Babasaheb Ambedkar: Writings and Speeches. New Delhi: Dr. Ambedkar Foundation.

AMBEDKAR, B. R. (2017). Annihilation of Caste: The Annoted Critical Edition. Navayana: New Delhi.

BENJAMIN, W. (2020). Walter Benjamin Quotes Quotable Quote. Retrieved from goodreads: https://www.goodreads.com/quotes/8265064-mankind-which-in-homer-s-time-was-anobject-of-contemplation

BILGRAMI, A. (2003). "Gandhi, the Philosopher". Economic and Political Weekly, 38 (39): 4159-4165.

CHAKRABARTY, B. (2017, February). “Gandhi’s Doctrine of Trusteeship: Spiritualizing Interpersonal Relationship". Retrieved from http://ncds.nic.in/sites/default/files/WorkingandOccasionalPapers/WP67NCDS.pdf

CHAUHAN, M. (2019). "Relevance of Gram Swaraj, Panchayati Raj Institutions and Trusteeship in Rural Context”. Social Action, 69: 261-372.

CORTES, C. R. (2020, October). Gates to a Global Empire: Over Seed, Food, Health, Knowledge and The Earth. Retrieved from Navdanya International: https://navdanyainternational.org/wp-content/uploads/2020/10/GATES-TO-A-GLOBALEMPIRE-REPORT-SYNTHESIS-13.10.2020-3.pdf

DALTON, D. (1993). Mahatma Gandhi: Non-Violent Power in Action. New York.

DENTICO, N. (2020). The Philanthropic Monopoly of Bill and Melinda Gates. Retrieved from Colonising Global Health: https://navdanyainternational.org/wpcontent/uploads/2020/10/THE-PHILANTHROPIC-MONOPOLY-OF-BMGF.pdf

FORUM, W. E. (2020). The Global Social Mobility Report 2020: Equality, Opportunity and a New Economic Imperative. Retrieved from http://www3.weforum.org/docs/Global_Social_Mobility_Report.pdf

FRENCH, V. (1934). Lord Willingdon in India. Bombay: Karnatak Printing Press.

GANDHI, M. K. (1929). “Speech at Students' Meeting, Rangoon”. In: Collected Works of Mahatma Gandhi (Vol. 45, p. 209).

GANDHI, M. K. (1938). Hind Swaraj or Indian Home Rule. Ahmedabad: Navajivan Publishing House. 
GANDHI, M. K. (1941). Constructive Programme: Its Meaning and Place. Ahmedabad: Navajivan Mudranalaya. Retrieved from https:/www.mkgandhi.org/cnstrct/cnstrct.htm

GANDHI, M. K. (1947). India of My Dreams. (R. K. Prabhu, Ed.) Ahmedabad: Navajivan Publishing House.

GANDHI, M. K. (1956). Unto This Last. (V. G. Desai, Trans.) Ahmedabad: Navajivan Mudranalaya.

GANDHI, M. K. (1960). Trusteeship. Ahmedabad: Navajivan Mudranalaya.

GANDHI, M. K. (1999). "Discussion with a Capitalist”. In: M. K. Gandhi, The Collected Works of Mahatma Gandhi (Vol.43, pp.412-413). New Delhi: Publications Division Government of India.

GANDHI, M. K. (1999). “Mr. Supposed Inconsistency”. In: The Collected Works of Mahatma Gandhi (Vol. 65). New Delhi: Publications Division Government of India.

GANDHI, M. K. (1999). "Speech at Moulmein". In: M. K. Gandhi, The Collected Works of Mahatma Gandhi (Vol. 45). New Delhi: Publications Division Government of India.

GANDHI, M. K. (1999). The Collected Works of Mahatma Gandhi. New Delhi: Publications Division Government of India.

GANDHI, M. K. (1999). "The Great Sentinel”. In: M. K. Gandhi, The Collected Works of Mahatma Gandhi (Vol. 24). New Delhi: Publications Division Government of India.

GANDHI, M. K. (1999). “The Same Old Argument". In M. K. Gandhi, The Collected Works of Mahatma Gandhi (Vol. 36, pp. 381-383). New Delhi: Publications Division Government of India.

GANDHI, R. (2019, October 7). Cosmopolitan Nationalist. India Today, pp. 37-39.

GUHA, R. (2014, September 14). “The aam aadmi behind Attenborough's Gandhi”. Retrieved from Hindustan Times: https://www.hindustantimes.com/columns/the-aam-aadmi-behindattenborough-s-gandhi/story-MnQTQj7haxzxtQoCAiEDkN.html

GUHA, R. (2018). Gandhi: The Years that Changed the World. Gurgaon: Penguin Random House.

GURUKKAL, R. (2012, September-October 2012). "Convergence of Marx and Gandhi: A Strategic Need Today". Social Scientist, 40 (9/10): 61-69. Retrieved from https://www.jstor.org/stable/23338884

HIMANSHU. (n.d.). India: Extreme Inequality in Numbers. Retrieved from Oxfam International: https://www.oxfam.org/en/india-extreme-inequality-numbers

KAISER-SCHATZLEIN, R. (2019, September 30). The Tyranny of Economists. Retrieved from The New Republic: https://newrepublic.com/article/155205/tyranny-economists 
KUMARAPPA, J. (1945). Economy of Permanence. Varanasi: Sarva Seva Sangh Prakashan.

MAHAPATRA, R. (2020, July 23). COVID-19: The Pandemic of Inequality. Retrieved from Down to Earth: https://www.downtoearth.org.in/blog/economy/covid-19-the-pandemicof-inequality-72442

MAHAPATRA, R. (2020, January 21). How India remains poor: 'It will take 7 generations for India's poor to reach mean income'. Retrieved from Down to Earth: https://www.downtoearth.org.in/news/economy/how-india-remains-poor-it-will-take-7generations-for-india-s-poor-to-reach-mean-income--68898

MASHRUWALA, K. G. (1951). Gandhi and Marx. Ahmedabad: Navajivan Publishing House.

MATHAI, M. P. (2019, October). “Quest for an Alternative Vision”. Yojana, 13-16.

MEHTA, V. (1976). Mahatma Gandhi and His Apostles. New York: The Viking Press.

MISHRA, P. (2017). Age of Anger: A History of the Present. New Delhi: Juggernaut.

MUKHERJEE, A. (2016). "The Indian Working Class and the National Movement". In: B. Chandra, M. Mukherjee, A. Mukherjee, K. N. Panikkar, \& S. Mahajan, India's Struggle for Independence. Harmondsworth: Penguin.

PAREL, A. J. (2006). Gandhi's Philosophy and the Quest for Harmony. Cambridge: Cambridge University Press.

PREMJI, A. (2013). Letter from Azim Premji for the first international Giving Pledge group. Retrieved from The Giving Pledge: https://givingpledge.org/Pledger.aspx?id=269

RAO, V. K. (1970). The Gandhian Alternative to Western Socialism. Bombay: Bharatiya Vidya Bhavan.

ROSEN, G. (1982, Jun). "Gandhian Economics: A Schumpeterian Perspective". Journal of Economic Issues, 16 (2): 435-438. Retrieved from https://www.jstor.org/stable/4225180

ROY, A. (2017). The Doctor and the Saint: Caste, Race, and Annihilation of Caste: The Debate between BR Ambedkar and MK Gandhi. New Delhi: Navayana.

SHIVA, D. V. (2015, August 14). An Agenda for Freedom from Hunger, Malnutrition, Disease and Farmers Suicides. Retrieved from Seed Freedom: https://seedfreedom.info/annaswaraj-food-sovereignty-2020/

SHRIVASTAVSA, A., \& KOTHARI, A. (2012). Globalisation in India: Impacts and Alternatives. Kalpavriksh. 
SINGH, R. B. (2006). Gandhian Approach to Development Planning (Vol. 28). New Delhi: Concept Publishing Company.

SRINIVAS, M. N. (1995, Jun 24). “Gandhi's Religion”. Economic and Political Weekly, 30 (25): 1489-1491. Retrieved from https://www.jstor.org/stable/4402906

STROM, S. (2010, November 10). Pledge to Give Away Fortunes Stirs Debate. Retrieved from The New York Times: https://www.nytimes.com/2010/11/11/giving/11PLEDGE.html?auth=login-google

SUHRUB, T. (2019, October 7). A Moral Economy. India Today, pp. 44-46.

THE GIVING PLEDGE. (n.d.). Retrieved from History of the Pledge: https://givingpledge.org/About.aspx

WOOD, A. W. (2014). The Free Development of Each: Studies on Freedom, Right, and Ethics in Classical German Philosophy. Oxford University Press.

SteFY V JosePH is Assistant Professor at the Department of International Studies, Political Science and History, CHRIST University, Bangalore. Her areas of research interest include Indian Politics, Diplomacy, Foreign Policy Studies and Maritime Studies.

MuCheli RishVANTH REDDY is pursuing a Bachelor of Arts in Economics, Political Science and Sociology from CHRIST University, Bangalore. He was editor and contributor of "Constructive Programme: A Manifesto for New Indi"” and "Musings on the Mahatma". His areas of research interest include Indian Politics and Gandhian Studies. 